\title{
Vendor Documentation
}

National Cancer Institute

\section{Source}

National Cancer Institute. Vendor Documentation. NCI Thesaurus. Code C115742.

Records pertaining to a specific vendor. 